\title{
Use of Mining Tailings or Their Sedimentation and Flotation Fractions in a Mixture with Soil to Produce Structural Ceramics
}

\author{
Igor B C. Amaral ${ }^{1, *}$, Luis Carlos D. Cavalcante ${ }^{2} \mathbb{D}$, José D. Fabris ${ }^{3}$, Bernat V. Prat ${ }^{1}$ and Arlete B. Reis ${ }^{4} \mathbb{D}$ \\ 1 JK Campus, Institute of Science and Technology (ICT), Bachelor of Science and Technology, Federal \\ University of the Jequitinhonha and Mucuri Valleys (UFVJM), Diamantina 39100-000, Minas Gerais, Brazil; \\ bernat.vinolas@ict.ufvjm.edu.br \\ 2 Center of Natural Sciences, Federal University of Piauí (UFPI), Teresina 64049-550, Piauí, Brazil; \\ cavalcanteufpi@ufpi.edu.br \\ 3 Department of Chemistry ICEx, Federal University of Minas Gerais (UFMG), Av. Antônio Carlos, \\ 6627-Pampulha, Belo Horizonte 31270-901, Minas Gerais, Brazil; jdfabris@gmail.com \\ 4 JK Campus, Institute of Science and Technology (ICT), Chemical Engineering, Federal University of the \\ Jequitinhonha and Mucuri Valleys (UFVJM), Diamantina 39100-000, Minas Gerais, Brazil; \\ arlete.reis@ict.ufvjm.edu.br \\ * Correspondence: igorbrumano@gmail.com; Tel.: +55-31-98704-3990
}

Citation: Amaral, I.BC.; Cavalcante, L.C.D.; Fabris, J.D.; Prat, B.V.; Reis, A.B. Use of Mining Tailings or Their Sedimentation and Flotation Fractions in a Mixture with Soil to Produce Structural Ceramics. Sustainability 2021, 13, 911. https:// doi.org/10.3390/su13020911

Received: 7 December 2020

Accepted: 24 December 2020

Published: 18 January 202

Publisher's Note: MDPI stays neutral with regard to jurisdictional claims in published maps and institutional affiliations.

Copyright: (C) 2021 by the authors. Licensee MDPI, Basel, Switzerland. This article is an open access article distributed under the terms and conditions of the Creative Commons Attribution (CC BY) license (https:/ / creativecommons.org/licenses/by/ $4.0 /)$.

\begin{abstract}
The ceramic materials industry has vast potential for use of waste from industrial processes, such as iron mining tailings. The aim of this study was to test technological use of tailings samples from the dam rupture of the Samarco S.A. Company in 2015 to produce structural ceramics. Sedimentation and flotation processes were used to improve their characteristics, analyzing their chemical and mineralogical composition and granulometry. We produced 48 samples with a mixture of soil and residues in proportions of 10,20 , and $30 \mathrm{wt} \%$, with sintering at $950{ }^{\circ} \mathrm{C}$. The results showed that co-processing of iron mining tailings can be considered viable for improving certain aspects of some technological properties. The maximum amount of residue used was $30 \mathrm{wt} \%$ for any of the fractions used, as above this concentration the specimens lose important characteristics.
\end{abstract}

Keywords: sedimentation; flotation; structural ceramics

\section{Introduction}

Brazil has a major presence in the ceramic materials industry with $4.8 \%$ of the construction sector, with an annual revenue of $\mathrm{U} \$ 4.5$ billion and an estimated production of 63.6 billion pieces/year, which corresponds to an estimated use of $140 \mathrm{Mt}$ of clay [1,2]. Therefore, the ceramic materials industry is a viable alternative for incorporation of tailings from numerous industrial activities such as extraction and processing of iron ore. The Alegria mine, in Mariana (MG, Brazil), controlled by the Samarco S.A. mining company, represents $7.86 \%$ of national iron ore production. The mine's tailings dam broke in November 2015, spreading 43.7 million cubic meters of mud along the Doce River, with 10.5 million cubic meters being retained by the Candonga dam of the Risoleta Neves hydroelectric power plant, between the municipalities of Rio Doce and Santa Cruz do Escalvado, in the state of Minas Gerais, Brazil.

The aim of this study was to test technological use of samples of these iron ore tailings from the Candonga Dam for production of structural ceramics, adding value to products to generate positive social and economic impacts in the production region of these materials, besides proposing a viable destination for tailings with an efficient environmental gain.

Iron ore exploitation in the state of Minas Gerais generates a substantial volume of tailings, the denomination given to remaining portions of soil after ore extraction. These tailings have a high moisture content, so they are dammed next to mines, which causes large environmental impacts in such areas, besides the recurring risk of rupture and downstream destruction. On 5 November 2015, rupture of the Fundão dam, which belongs to the 
Samarco mining company, hit over 40 cities in the states of Minas Gerais and Espírito Santo, even reaching the sea, mainly affecting districts of Mariana (MG), as well as the bed of the Doce River downstream of the dam. It is considered the largest environmental disaster in Brazil, killing 19 people and depositing a large volume of tailings along the course of the river [3,4]. On 25 January 2019, another mining tailings dam broke in Minas Gerais, this time with a smaller volume of tailings but causing a higher number of human victims.

This study is therefore justified by the relevance of technological development regarding the reuse of mining tailings, their appeal and consequent decrease in the use of dams for deposition of this material. Thus, our aim is to evaluate the technological use of iron ore tailings for ceramics production for the construction sector.

In the co-processing proposed in this study, we used separation processes to obtain fractions of ore tailings to use in admixture with a soil, with the aim of improving the characteristics of ceramic pieces produced using sedimentation and flotation operations [5]. Mining companies use both processes to benefit iron ore, but they consign the resulting fractions to dams. Therefore, besides the proposed destination of the generated tailings, we suggest future actions regarding reuse to produce structural ceramics, offering a new method for mining industries since these companies execute similar processes, although the benefited phases are mixed prior to disposal. As such, the proposition of a destination for tailings prior to their disposal opens up the possibility of their redirection soon after ore extraction processes executed by miners.

Considering the mentioned context, the main aim of this study was to investigate the use of different proportions of iron ore mining tailings or their fractions in a mixture with soil, in the composition of ceramic masses and to test their effects on the properties of the produced pieces through physical, chemical and mechanical tests.

\section{Materials and Methods}

The tailing samples explored in this study come from the Candonga dam, between the municipalities of Rio Doce and Santa Cruz do Escalvado, in the Zona da Mata Region in Minas Gerais, Brazil. The iron ore tailings deposited in this dam come from the breach of the Fundão dam, in Mariana (MG). The soil comes from the Cerâmica Baixio pottery in São João do Oriente (MG). The soil samples studied were collected from the storage area of Cerâmica Baixio and selected randomly, aiming at representativeness of the raw material used by the company.

Description of the materials and experimental procedures used to characterize the raw materials and sintered specimens was separated into four parts. First, the sedimentation and flotation processes used to obtain the tailings fractions are described. In the second part, the materials and methods adopted for characterization of raw materials (soil, tailings, and fractions of tailings) are presented, along with a discussion on the characterization techniques used. In the third part, the preliminary procedures of specimen production are described, including formulation of masses with the proportions of tailings and their fractions, and the experimental procedure adopted for molding, drying, and sintering. In the fourth part, the methods used in the trials evaluating the technological properties of the specimens are described.

\subsection{Sedimentation and Flotation Processes to Obtain Tailings Fractions (Part I)}

The sedimentation procedure was conducted after dispersion of $500 \mathrm{~g}$ of tailings in $500 \mathrm{~mL}$ of water $(50 \mathrm{wt} \%)$ and $\mathrm{pH}$ adjustment to 10.5 with the addition of sodium hydroxide (NaOH). A $1000 \mathrm{~mL}$ beaker was used and sedimentation time was $10 \mathrm{~min}$, after which the settling zone was drained and placed in a heat chamber at $105 \pm 5^{\circ} \mathrm{C}$, and the sludge zone was moved to a $1000 \mathrm{~mL}$ beaker and placed in a heat chamber for drying.

For the flotation process, the same colloidal dispersion was carried out with $500 \mathrm{~g}$ of tailings in $500 \mathrm{~mL}$ of water $(50 \mathrm{wt} \%)$ and $\mathrm{pH} 10.5$, adjusted with the addition of sodium hydroxide. The flotation process was performed with the use of a horizontal flotation module, using cornstarch as a depressant to increase the hydrophilic behavior of hematite, 
reducing the buoyancy of particles [6], and amine as a collector, acting as a stabilizer of foam and collector of quartz minerals [7].

\subsection{Characterization of Raw Materials (Part II)}

The granulometry of the soil is related to plasticity and other properties of ceramic mass, whereby clays with very fine granulometry (less than $2 \mu \mathrm{m}$ ) have greater plasticity and high chemical reactivity, whereas clays containing thicker grains, with granulometry above $60 \mu \mathrm{m}$ [8-10], are characterized as presenting less plasticity and specific surface, but greater thermal stability. Granulometric analysis was performed in a laser granulometer, model CILAS 1190 Particle Size Analyzer, at the Nuclear Fuel Laboratory (LABCON) of the Center for the Development of Nuclear Technology (CDTN), with a reading range of $0.04 \mu \mathrm{m}$ to $2500.00 \mu \mathrm{m}$. Approximately $5 \mathrm{~g}$ of material were dispersed in $50 \mathrm{~mL}$ of water and reading was carried out in $60 \mathrm{~s}$ on an ultrasonic device with dispersing function for particles.

The crystalline phases of the soil samples, mining tailings, and tailings fractions were analyzed using X-ray diffractometry (XRD) of the powder using a Rigaku diffractometer, model D/MAX Ultima Plus, with copper tube $(\lambda=1.541838 \AA)$, voltage of $40 \mathrm{kV}$ and current of $30 \mathrm{~mA}$, at the X-ray Diffraction Laboratory/Service of Mineral Technology—SETEM of the CDTN. XRD scanning was in the range of 0 to $80^{\circ}(2 \theta)$, with a velocity of $4^{\circ}(2 \theta) \mathrm{min}^{-1}$.

Elemental chemical composition determination of materials with grain size $<75 \mu \mathrm{m}$ was carried out through energy dispersive $X$-ray fluorescence using a Shimadzu EDX-720 spectrometer, detecting chemical elements with an atomic number between sodium $(Z=11)$ and uranium $(Z=92)$, at the LIPEMVALE/UFVJM Multiuser Laboratory. In this technique, the sample was irradiated for a short time using high-intensity polychromatic X-rays, which have their energy absorbed by the sample, causing displacement of orbital electrons and resulting in an X-ray emission spectrum characteristic of each component chemical element [11].

\subsection{Production of Test Pieces (Part III)}

The manufacturing process of ceramics involves at least four steps: Preparation of raw materials by grinding; mixing and conformation of a ceramic mass with the addition of water and the extrusion of pieces or pressing in a mold; drying, which may be natural or artificial; and sintering, in which pieces gain their final properties [12,13]. Some products may need other steps for finishing, which we shall not address in this study, since production of structural ceramics does not require post-firing treatment.

The soil used in this study has a much higher concentration of silica than iron minerals, so it has a more yellowish tone, while tailings and their fractions have a higher concentration of hematite and goethite, showing a more reddish color. These tonality characteristics were tested in specimens through qualitative analysis with the Munsell soil color charts [14].

The experiment was designed considering the variables involved in the process of manufacturing specimens, the percentage of tailings or their fractions added to the soil, setting temperature and firing level. Contents of 10, 20 and $30 \mathrm{wt} \%$ of analyzed tailings or their fractions were used in partial replacement of soil in the ceramic mass. Test specimens prepared only with soil without addition of tailings were also used as controls. Firing temperature was set at $950{ }^{\circ} \mathrm{C}$. At the end of pressing process, all the specimens were named for easy identification and subsequent analysis. The nomenclature was organized according to the variables considered here, using letters " $A$ " for soil, " $R$ " for tailings, " $S$ " for sludge zone, " $\mathrm{C}$ " for sedimentation settling zone, " $\mathrm{N}$ " for non-floated, and " $\mathrm{F}$ " for floated in the flotation process, accompanied by percentages of tailings or fractions added to each formulation. For example: Test piece S20 contains $20 \mathrm{wt} \%$ bottom sedimentation (sludge zone) and $80 \mathrm{wt} \%$ soil, and so on. In this study, mass compaction occurred through molding in a rectangular metal mold of $20 \times 60 \mathrm{~mm}$. The moisture content used for mixing the mass and shaping in the molds was $10 \mathrm{wt} \%$, the minimum required for good workability and 
molding, given the particle size of the samples. A uniaxial press with a pressure of $20 \mathrm{MPa}$ $\left(200 \mathrm{kgf} / \mathrm{cm}^{2}\right)$ was applied to specimens [12] for five minutes using a P60100 BOVENAU hydraulic press with a capacity of 60 tons.

Drying was carried out in a LUCA-82 oven at $105 \pm 5{ }^{\circ} \mathrm{C}$ for $24 \mathrm{~h}$ until the difference between successive weighings at $1 \mathrm{~h}$ intervals did not exceed $0.1 \%$. For firing, the rapid sintering cycle $\left(15^{\circ} \mathrm{C} / \mathrm{min}\right)$ [15] in a MAGNU muffle oven was selected, with a first plateau of one hour at a temperature of $600{ }^{\circ} \mathrm{C}$ and a firing plateau of $120 \mathrm{~min}$ at a temperature of $950{ }^{\circ} \mathrm{C}$. Natural cooling was used with the furnace being turned off and opened after $24 \mathrm{~h}$, with the samples being removed when internal temperature of the muffle oven corresponded to room temperature.

\subsection{Evaluation of Technological Properties of Test Bodies (Part IV)}

Tests of linear shrinkage (LS), mass loss (ML), water absorption (WA), apparent porosity (AP), coloration, and scanning electron microscopy (SEM) were performed to analyze the physical properties of the ceramic materials produced. Flexural strength $(\sigma)$ tests were used to verify the strength of the specimens to mechanical stresses.

All the results of the tests performed in this study were verified using Tukey's test, after checking normality and independence of data and homogeneity of variance, to verify if there was a statistically significant difference between the values obtained in each test. In cases where the results did not follow normal distribution, the Kruskal Wallis test was used to verify if there was a difference between data and the Tukey HSD (honestly significant difference) test to analyze which data most differed from one other.

Linear shrinkage presents the sum of the contraction presented by test specimens after drying, called drying linear shrinkage and sintering linear shrinkage. A digital caliper with $0.01 \mathrm{~mm}$ resolution was used to measure the dimensions of specimens. The values for linear shrinkage will be positive when there is retraction and negative when there is expansion; its definition is important to establish dimensions of the molds used, with preference for the use of soils with low LS values.

Mass loss is the difference in mass between drying $\left(105 \pm 5^{\circ} \mathrm{C}\right)$ and sintering $\left(950{ }^{\circ} \mathrm{C}\right)$. It occurs mainly as a result of loss of coordinated and adsorbed waters, hydroxyls of clay minerals $\left(\mathrm{Al}(\mathrm{OH})_{3}\right.$ and $\left.\mathrm{Fe}(\mathrm{OH})_{3}\right)$, carbon dioxide and sulfur, organic matter, and volatile components [10,16-18]. To determine this parameter, a Shimadzu AUY220 analytical balance with a capacity of $220 \mathrm{~g}$ and an accuracy of $0.1 \mathrm{mg}$ was used. It is known that the higher the sintering temperature and organic matter content, the greater the mass loss to fire, due to release of a larger amount of oxidized carbon and oxygen. To reduce ML, it is essential that the drying process is effective, eliminating as much water as possible during this step [19].

Coloration analysis was used as a preliminary screening test, since red is not always indicative of the characteristics desired for ceramic products (structural ceramics), and there are clays poor in ferruginous species that produce light-colored ceramics with satisfactory characteristics [13]. In this study, the Munsell Chart was used for a qualitative analysis of product color and more detailed classification of specimen tone variation. Coloring is given according to nomenclature, value, and chroma proposed in soil color charts [14].

To perform a Water Absorption test, the dry sintered specimens must be weighed and then submerged in water at room temperature for $24 \mathrm{~h}$, or in boiling water for $2 \mathrm{~h}$. After this time, the specimens are taken out of the liquid and excess surface water is removed with a damp cloth and the specimen weighed again; water absorption is calculated according to the Brazilian norm NBR 15270-1 [20]. In ceramic and structural ceramic blocks, water absorption must be over $8 \%$ and less than $22 \%$ [20], because blocks with high water absorption have problems with mortar adhesion [21]. For ceramic tile production, water absorption needs to be less than $20 \%$ [20].

Apparent Porosity presents the measured percentage of the volume of the test specimens' open pores, based on Archimedes' principle of immersion in water at room temperature. The required porosity value must be below $20 \%$ to maintain the mechanical 
integrity of the pieces during transportation. However, porosity facilitates the drying process, avoiding defects caused by gas evaporation. It is known that porosity and water absorption are related to each other and inversely related to the occurrence of molten flux in raw material composition, which fills the pores during formation in the melted phase $[9,22]$.

Flexural strength $(\sigma)$ or bending rupture stress from the three-point flexure test was obtained using a $4 \mathrm{kN}$ load cell bending test press from the Construction Materials Laboratory, at the Federal University of Viçosa (UFV). Test specimens had their three dimensions measured with a caliper and, after rupture in the test, flexural strength was calculated according to rupture load. Flexural strength is related to porosity properties of material, such as AP and WA, and firing temperature, since denser products have higher mechanical strength $[9,17,23]$. The flexural strength test is very useful for ceramic tile production, as they are most requested in relation to bending during their lifetime, during transportation, handling and assembly, or even after installation, when the user may need to transit over the tiles [10]. Thus, NBR 15,310 [24] defines $130 \mathrm{kgf}$ as the minimum limit for flexural load for composite tiles and $100 \mathrm{kgf}$ for other types.

Scanning electron microscopy (SEM) was used for qualitative identification of surface porosity and the occurrence of micro-cracks in ceramic pieces. In this study, a Shimadzu scanning electron microscope, model SSX-550, was used, at the X-Ray Diffraction Laboratory of the Department of Chemistry of UFVJM, with electron acceleration between $20 \mathrm{kV}$.

\section{Results}

The yield of the sedimentation process from the mining tailing was $17.5 \%$ settling zone and $82.5 \%$ sludge zone, and the yield obtained in the flotation process was $49 \%$ floated and $51 \%$ non-floated.

The data obtained in the granulometric analysis performed with a laser granulometer show that the soil collected from the Cerâmica Baixio pottery has a clay fraction of $10.05 \%$, $82.15 \%$ silt, and only $7.80 \%$ fine sand, while the tailings contain $6.20 \%$ clay, $53.69 \%$ silt, and $40.11 \%$ fine sand. In the sedimentation process, we observed that the settling zone contained a portion of smaller particles, presenting a clay fraction of $17.42 \%$ and $82.58 \%$ silt, without the occurrence of a sandy fraction, while the sludge zone presented only $4.05 \%$ clay, $57.40 \%$ silt, and $38.55 \%$ sand. In flotation, there was $6.37 \%$ and $3.75 \%$ clay, $61.90 \%$ and $33.40 \%$ silt, and 31.73 and $62.85 \%$ of sand, for the floated and non-floated portions, respectively. Figure 1 presents granulometric composition according to the distribution of particle size based on clay, silt, and sand.

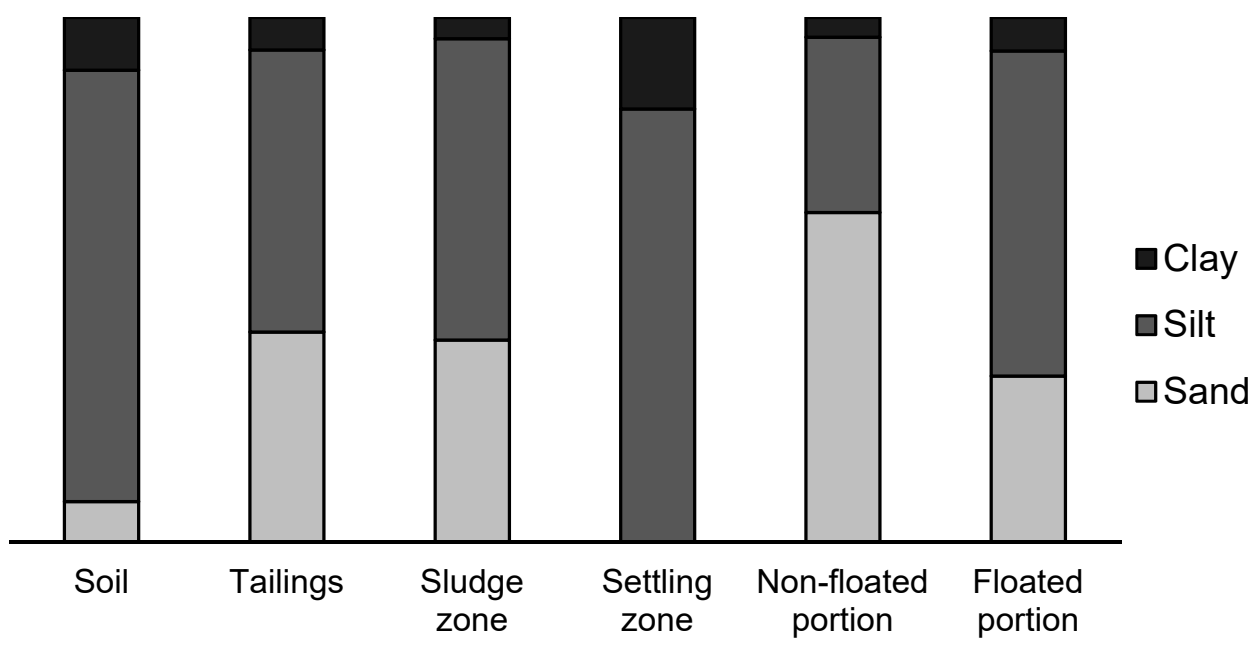

Figure 1. Particle size of raw materials based on clay, silt, and sand. 
All the raw materials have low clay content, and, individually, are outside the most important range for the production of structural ceramics $(<2 \mu \mathrm{m})$, as, according to the McManus diagram [25], coarse particle size has high permeability and porosity, impairing workability and consistency. Therefore, we required a higher moisture content in molding or use of preliminary mechanical grinding [25-27].

The results of the elemental chemical composition, as determined by X-ray fluorescence (XRF), are shown in Table 1, and Figure 2 shows the X-ray diffraction patterns of the soil and mining tailing samples (proportions of the corresponding mineral phases in Table 1). The soil is composed of quartz, kaolinite, microcline, and rutile, while the tailings contain quartz, hematite, goethite, and kaolinite. By analyzing the diffractograms of different fractions of sedimentation and flotation (Figure 3 and Table 2), a significant difference can be observed between compositions. The sludge zone did not contain kaolinite, while the settling zone concentrated all the clay minerals and a smaller amount of quartz. The non-floated fraction of the flotation process concentrated hematite and a larger amount of goethite of the mining tailings, although the floated fraction showed a small amount of iron minerals and had, similarly to the settling zone, concentrated the clay minerals of said tailings.

Table 1. Results of mineralogical and elemental chemical analyses of soil and tailing samples.

\begin{tabular}{ccccc}
\hline \multirow{3}{*}{ Soil } & Minerals-XRD & $\%$ & Oxides-XRF & Mass\% \\
& Quartz & 53.2 & $\mathrm{SiO}_{2}$ & 43.26 \\
& Kaolinite & 32.9 & $\mathrm{Al}_{2} \mathrm{O}_{3}$ & 35.58 \\
& Microcline & 12.7 & $\mathrm{Fe}_{2} \mathrm{O}_{3}$ & 16.13 \\
& Rutile & 1.2 & $\mathrm{~K}_{2} \mathrm{O}^{2}$ & 2.33 \\
& & $\mathrm{TiO}_{2}$ & 1.13 \\
& & $\mathrm{CaO}$ & 0.59 \\
& & & $\mathrm{Others}^{2}$ & 0.98 \\
\hline \multirow{7}{*}{ Tailing } & Quartz & 79.3 & $\mathrm{SiO}_{2}$ & 47.22 \\
& Hematite & 10.2 & $\mathrm{Fe}_{2} \mathrm{O}_{3}$ & 37.11 \\
& Goethite & 9.9 & $\mathrm{Al}_{2} \mathrm{O}_{3}$ & 15.00 \\
& Kaolinite & 0.6 & $\mathrm{~K}_{2} \mathrm{O}$ & 0.41 \\
& & & $\mathrm{CaO}$ & 0.11 \\
& & & Others & 0.15 \\
\hline
\end{tabular}
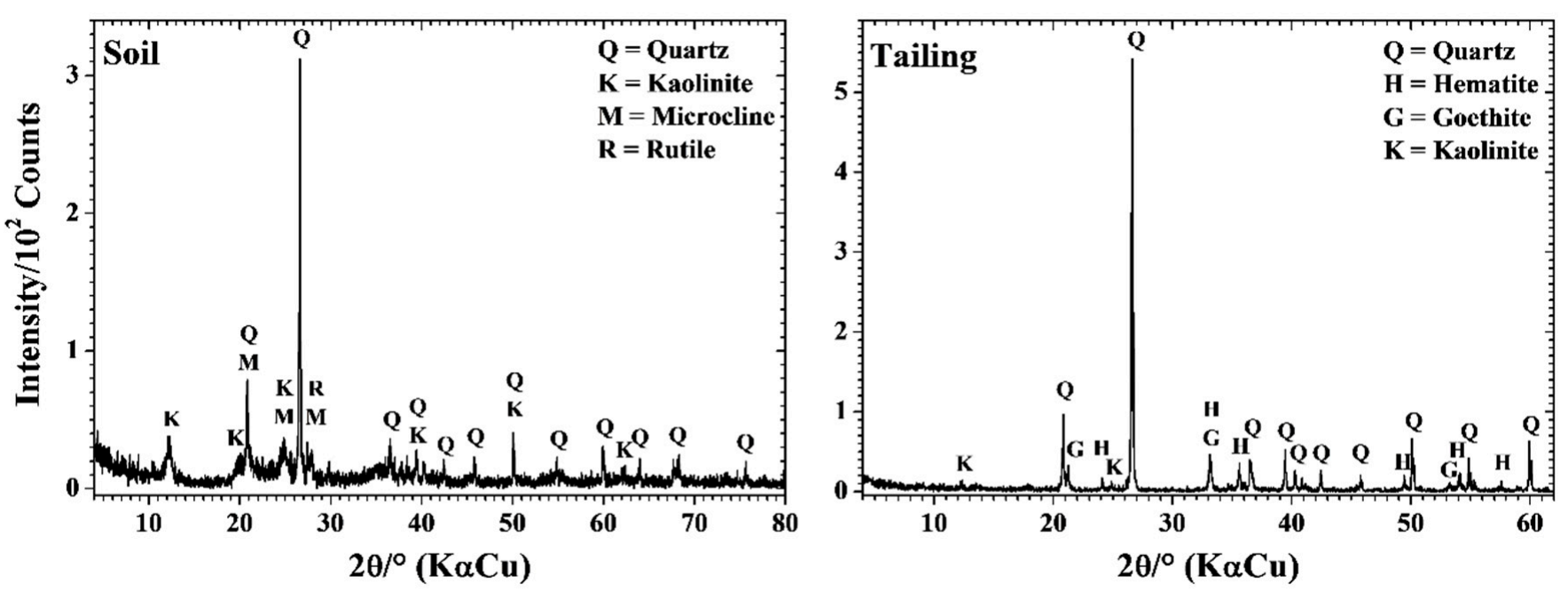

Figure 2. Powder XRD patterns for the soil and tailing samples. 

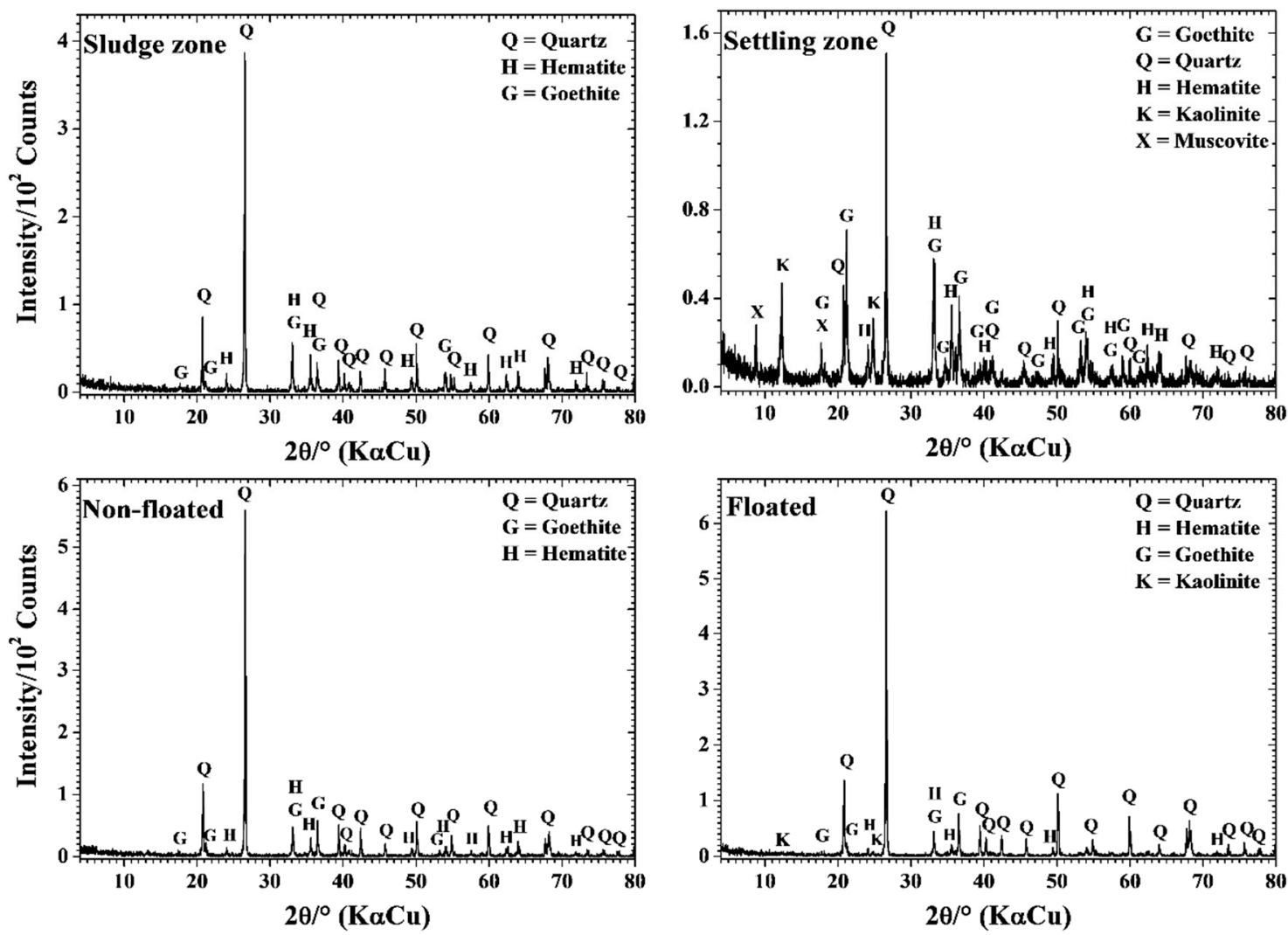

Figure 3. Powder XRD patterns for the sludge zone and settling zone samples (sedimentation process) and for the floated and non-floated fractions (flotation process).

Table 2. Results of mineralogical and elemental chemical analyses of the sludge zone and settling zone (sedimentation process) and floated and non-floated fractions (flotation process).

\begin{tabular}{|c|c|c|c|c|}
\hline & Minerals-XRD & $\%$ & Oxides-XRF & Mass \% \\
\hline \multirow[t]{6}{*}{ Sludge zone } & Quartz & 77.0 & $\mathrm{SiO}_{2}$ & 53.35 \\
\hline & Hematite & 17.2 & $\mathrm{Fe}_{2} \mathrm{O}_{3}$ & 35.74 \\
\hline & Goethite & 5.8 & $\mathrm{Al}_{2} \mathrm{O}_{3}$ & 10.43 \\
\hline & & & $\mathrm{K}_{2} \mathrm{O}$ & 0.29 \\
\hline & & & $\mathrm{MnO}$ & 0.12 \\
\hline & & & $\mathrm{CaO}$ & 0.07 \\
\hline \multirow[t]{6}{*}{ Settling zone } & Goethite & 42.6 & $\mathrm{Fe}_{2} \mathrm{O}_{3}$ & 52.26 \\
\hline & Quartz & 25.5 & $\mathrm{SiO}_{2}$ & 24.69 \\
\hline & Hematite & 19.5 & $\mathrm{Al}_{2} \mathrm{O}_{3}$ & 21.92 \\
\hline & Kaolinite & 10.3 & $\mathrm{~K}_{2} \mathrm{O}$ & 0.68 \\
\hline & Muscovite & 2.1 & $\mathrm{MnO}$ & 0.28 \\
\hline & & & $\mathrm{CaO}$ & 0.17 \\
\hline \multirow[t]{6}{*}{ Floated } & Quartz & 88.3 & $\mathrm{SiO}_{2}$ & 54.26 \\
\hline & Hematite & 6.4 & $\mathrm{Fe}_{2} \mathrm{O}_{3}$ & 28.85 \\
\hline & Goethite & 3.9 & $\mathrm{Al}_{2} \mathrm{O}_{3}$ & 16.03 \\
\hline & Kaolinite & 1.4 & $\mathrm{~K}_{2} \mathrm{O}$ & 0.62 \\
\hline & & & $\mathrm{MnO}$ & 0.14 \\
\hline & & & $\mathrm{CaO}$ & 0.10 \\
\hline \multirow[t]{6}{*}{ Non-floated } & Quartz & 79.3 & $\mathrm{SiO}_{2}$ & 45.78 \\
\hline & Goethite & 10.9 & $\mathrm{Fe}_{2} \mathrm{O}_{3}$ & 39.28 \\
\hline & Hematite & 9.8 & $\mathrm{Al}_{2} \mathrm{O}_{3}$ & 14.51 \\
\hline & & & $\mathrm{K}_{2} \mathrm{O}$ & 0.19 \\
\hline & & & $\mathrm{MnO}$ & 0.14 \\
\hline & & & $\mathrm{CaO}$ & 0.10 \\
\hline
\end{tabular}


The soil sample presented high levels of quartz (53.2\%) and kaolinite $(32.9 \%)$ and lower proportions of microcline (12.7\%) and rutile $(1.2 \%)$. The XRF analyses were useful for identifying the percentage of amorphous iron present in the sample, which is necessary for ceramic mass composition. The mineralogical composition of the Samarco S.A. mining tailing was $79.3 \%$ quartz, $10.2 \%$ hematite, $9.9 \%$ goethite, and $0.6 \%$ kaolinite. Therefore, the co-processing of iron ore tailings with soil is justified by the environmental issue of availability of mining tailings, as well as the increase in proportions of ferruginous species in the final mass.

The X-ray fluorescence (XRF) data for soil samples from Cerâmica Baixio show high silicon content (expressed as $\mathrm{SiO}_{2}$ ) in the soil, with a $\mathrm{SiO}_{2} / \mathrm{Al}_{2} \mathrm{O}_{3}$ ratio of $\sim 1.22$. The sum of silicon and aluminum contents (expressed as $\mathrm{SiO}_{2}$ and $\mathrm{Al}_{2} \mathrm{O}_{3}$, respectively) exceeds $78 \%$; the silicon occurs as clay-minerals and free quartz, and the aluminum as clay-minerals, mainly kaolinite [17]. The sum of the iron and titanium contents of $17.26 \%$ (expressed as $\mathrm{Fe}_{2} \mathrm{O}_{3}$ and $\mathrm{TiO}_{2}$, respectively) is above the recommended limit, which is below $10 \%[11,22]$. Likewise, the sum of the calcium and potassium proportions (expressed as $\mathrm{CaO}$ and $\mathrm{K}_{2} \mathrm{O}$, respectively), which act as molten fluxes in the clay mass, exceeds $2.9 \%$. Therefore, attention should be paid to the high iron content, which may darken the color of the products [28], but has the advantage of facilitating sintering at lower temperatures of around $750{ }^{\circ} \mathrm{C}$. The high Si contents contribute to increasing mechanical resistance and decreasing specimen retraction, behaving as a "skeleton" during the formation of the melted phase. The occurrence of potassium is compatible with the microcline (alkaline feldspar of chemical composition $\mathrm{KAlSi}_{3} \mathrm{O}_{8}$ ) identified by XRD.

Regarding the iron ore tailings from Samarco SA (Table 1), the high iron content (expressed as $\mathrm{Fe}_{2} \mathrm{O}_{3}$ ), of $37.11 \mathrm{wt} \%$ stands out, which leads to an increase in mixtures with a soil containing this quantity of molten fluxes and other elements, affecting the color of the product. The ratio of $\mathrm{SiO}_{2} / \mathrm{Al}_{2} \mathrm{O}_{3}$ in these tailings is $\sim 3.15$, because of the high quartz content, as detected through XRD analyses, such that the sum of proportions of these elements exceeds $62 \%$ of the chemical composition by mass.

After the sedimentation and flotation processes, the sludge zone and settling zone, and the floated and non-floated fractions also had their elemental chemical composition determined using XRF, and their mineral phases identified through XRD, as shown in Figure 3 and Table 2.

Regarding the sedimentation process, XRD analyses show a high concentration of quartz (77.0\%) and lower proportions of hematite (17.2\%) and goethite $(5.8 \%)$, with no signs of kaolinite and muscovite in the sludge zone, or bottom fraction. In the settling zone, there is a high concentration of ferruginous species, such as goethite $(42.6 \%)$ and hematite $(19.5 \%)$, and quartz $(25.5 \%)$, kaolinite $(10.3 \%)$, and muscovite $(2.1 \%)$. The high proportion of goethite and hematite in the settling zone thus pointed to the marked darkening of specimens produced with this fraction of tailings. As observed, XRF data showed higher silicon concentration (expressed as $\mathrm{SiO}_{2}$ ) in the sludge zone and iron (expressed as $\mathrm{Fe}_{2} \mathrm{O}_{3}$ ) in the settling zone. These results are compatible with data obtained through XRD, which showed $62.1 \%$ hematite and goethite to $37.9 \%$ quartz and clay minerals in the settling zone; and $23.0 \%$ iron minerals and $77.0 \%$ quartz in the sludge zone.

In relation to the flotation process, there was a smaller variation in silicon content (expressed as $\mathrm{SiO}_{2}$ ) in the floated and non-floated fractions (54.26 and 45.78\%, respectively) in relation to the corresponding content in the tailings ( $47.22 \mathrm{mass} \%)$; there being a concentration of kaolinite $(1.4 \%)$ and quartz $(88.3 \%)$ in the floated fraction, and a concentration of goethite $(10.9 \%)$ and hematite $(9.8 \%)$ in the non-floated fraction.

Due to the absence of kaolinite in the tailings and the high quartz content, the flotation process showed little effect on silica concentration in the floated fraction (quartz-88.3\% and kaolinite-1.4\%) when compared to the non-floated (quartz-79.3\%). However, in relation to iron minerals, the non-floated fraction had twice the sum of the percentages of iron minerals $(20.7 \%)$ when compared to the floated fraction $(10.3 \%)$, especially in relation to goethite $(10.9 \%$ in non-floated and $3.9 \%$ in floated). As for elemental chemical analysis, 
the floated fraction had a higher silicon content $\left(54.26 \%\right.$; expressed as $\left.\mathrm{SiO}_{2}\right)$ than the nonfloated fraction $(45.78 \%)$, which was due to the high proportion of silicates, clay minerals, and free quartz in the floated fraction. However, in relation to iron, due to the higher percentage of hematite and goethite in the non-floated fraction, the content (expressed as $\mathrm{Fe}_{2} \mathrm{O}_{3}$ ) was $39.28 \%$ in this fraction and $28.85 \mathrm{wt} \%$ in the floated fraction.

In relation to the raw materials used, the most expressive molten fluxes are related to the iron in the mining tailings. With this initial analysis, it was possible to predict the intensification of color of sintered specimens to which a proportion of these residues was added. Considering the above, it is possible to predict a greater difference between specimens produced with sedimentation fractions, since we identified a more significant difference between the mineralogical and elemental chemical composition of the two phases. The ternary diagram (Figure 4) shows the distribution of compositions in relation to the vertexes represented by $\mathrm{Si}$, showing the presence of free silica, $\mathrm{Al}$, as indicative of clay minerals, and the vertex composed of elements $\mathrm{Fe}$, Ti and $\mathrm{K}$, being considered the sum of the components of free oxides, carbonates and feldspars. In this representation, the proximity can be observed of the tailings in relation to sedimentation sludge, to floated and to non-floated, with a difference of close to $10 \%$ on the three vertexes. However, there is a distance from the settling zone, except for on the vertex composed of $\mathrm{Al}$, and from soil, especially on of the $\mathrm{Al}$ and the $\mathrm{Fe}, \mathrm{Ti}$, and $\mathrm{K}$ vertexes.

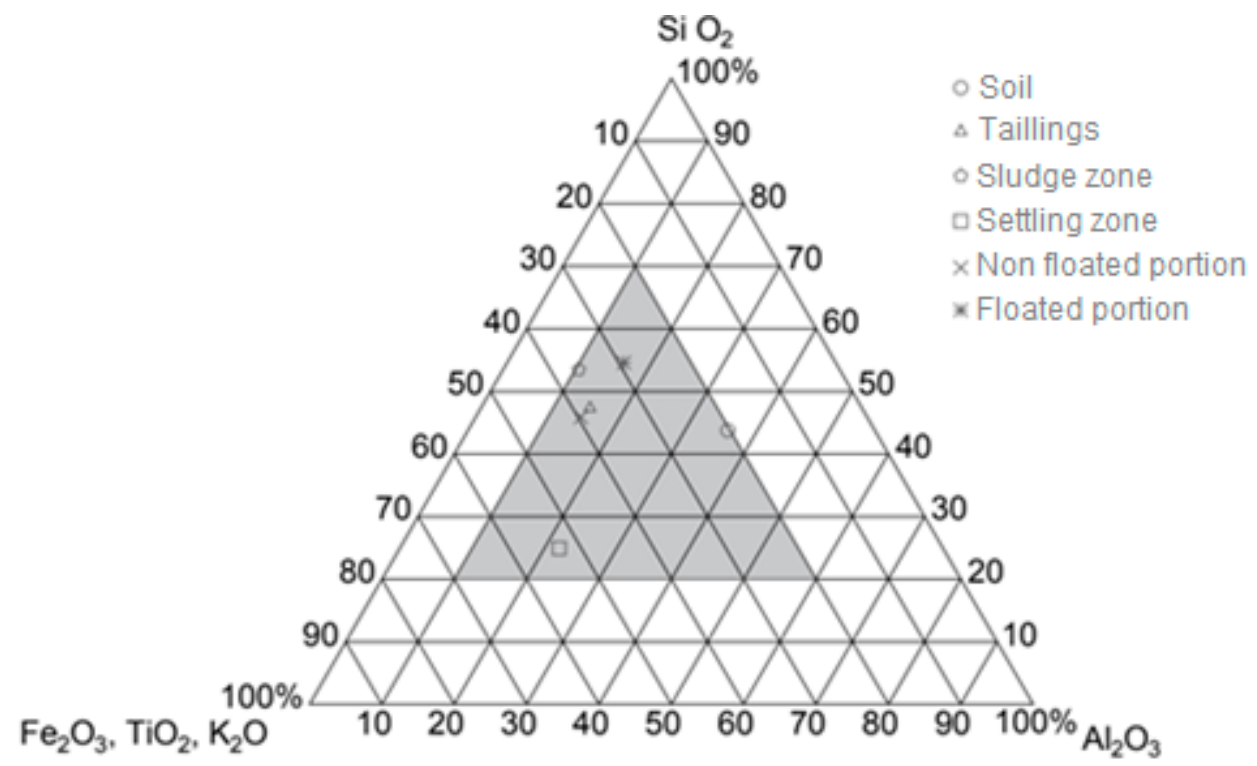

Figure 4. Tertiary diagram of $\mathrm{SiO}_{2} / \mathrm{Al}_{2} \mathrm{O}_{3} / \mathrm{Fe}_{2} \mathrm{O}_{3}+\mathrm{TiO}_{2}+\mathrm{K}_{2} \mathrm{O}$ system.

Regarding total linear shrinkage of the specimens, it was observed that the addition of tailings or their sedimentation and flotation fractions to clayey masses caused a decrease in the value of this parameter, except in the case of the settling zone, which retained an LS value closer to that recorded for the test specimen prepared with pure soil (Table 3). The Tukey test showed that the S20, N30, F30, and S30 test pieces were those that presented the best results for LS, followed by N20, F20, R10, and F10. Therefore, the use of the sludge zone from sedimentation, the non-floated fraction, and, above all, the floated fraction, resulted in a significant reduction of total linear shrinkage. Thus, it can be stated that for the formulations used in this study, LS was well below the maximum limit of $6 \%$ defined in the literature [13], thereby showing that the addition of iron ore tailings or their sedimentation and flotation fractions should not cause an increase in deformation or lead to the appearance of cracks in ceramic pieces produced. 
Table 3. Total linear shrinkage (LS: Mean value obtained for the formulations with contents of 10, 20 and $30 \mathrm{wt} \%$ of analyzed tailings or their fractions as partial replacement for soil in the ceramic mass) of specimens sintered at $950{ }^{\circ} \mathrm{C}$ according to the raw materials used in their formulation.

\begin{tabular}{cc}
\hline Formulation & LS/\% \\
\hline Soil & $1.51 \pm 0.19$ \\
Soil + tailings & $1.42 \pm 0.29$ \\
Soil + sludge zone & $1.20 \pm 0.18$ \\
Soil + settling zone & $1.47 \pm 0.09$ \\
Soil + non-floated fraction & $1.12 \pm 0.15$ \\
Soil + floated fraction & $0.94 \pm 0.16$ \\
\hline
\end{tabular}

Regarding the mass loss of specimens, a decrease was observed in this parameter with the addition of tailings or their fractions to soil mass (Figure 5). This may be due to the lower quantity of organic matter in these materials, which, when added to soil, contribute to decreasing the percentage of the organic phase in the final mass [29]. However, the addition of the settling zone resulted in a small increment in the ML value, which may be explained by the fact that organic matter has a lower density than other grains present in the tailings, which, therefore, remained floating in the sludge zone. We relate the excessive ML to porosity and linear shrinkage from sintering [15,17,19,29].

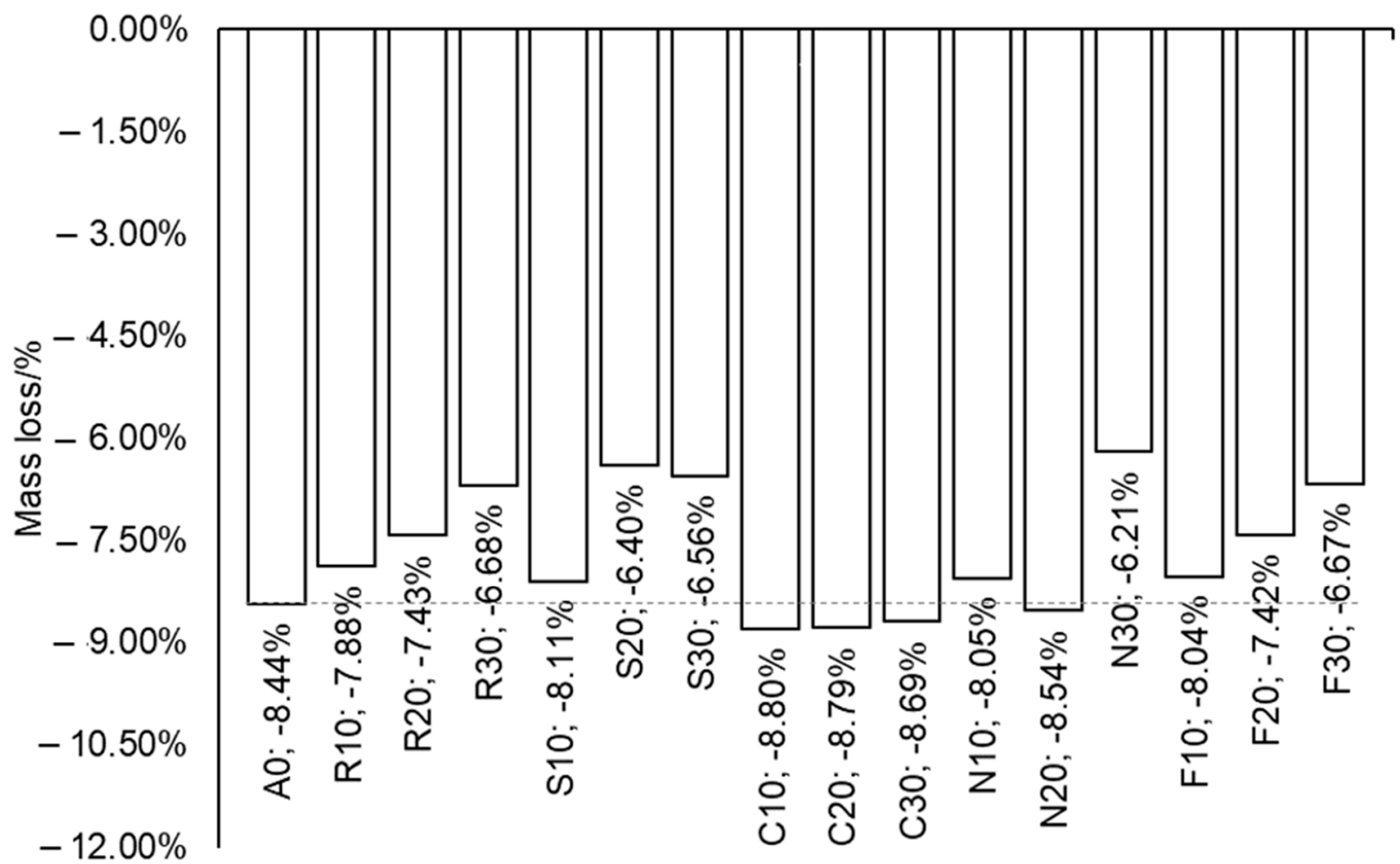

Figure 5. Mass loss of specimens with the addition of $0,10,20$, and $30 \mathrm{wt} \%$ of tailings, sludge zone, settling zone, non-floated and floated to the soil mass. A0 $=0 \mathrm{wt} \%$ residue; R10, $\mathrm{R} 20$ and $\mathrm{R} 30=10,20$, and $30 \mathrm{wt} \%$ pure tailing; S10, S20, S30 = 10, 20, and $30 \mathrm{wt} \%$ sludge zone; $\mathrm{C} 10, \mathrm{C} 20, \mathrm{C} 30=10,20$, and $30 \mathrm{wt} \%$ settling zone; N10, N20, N30 = 10, 20, and $30 \mathrm{wt} \%$ non-floated; $\mathrm{F} 10, \mathrm{~F} 20, \mathrm{~F} 30=10,20$, and $30 \mathrm{wt} \%$ floated.

Table 4 shows the colors of specimens determined visually and with the aid of the Munsell Chart. The variation in the amount of tailings or their fractions added to the soil did not change the color of test specimens, leaving only a few darker shades as the proportion of tailings increased, especially with the addition of the sludge zone and the non-floated, due to the higher amount of iron minerals present in these fractions of tailings [15]. 
Table 4. Coloring of test specimens with the addition of $0,10,20$, and $30 \mathrm{wt} \%$ of tailings, sludge zone, settling zone, non-floated, and floated to the soil mass. A0 $=0 \mathrm{wt} \%$ residue; R10, R20, and R30 = 10, 20, and $30 \mathrm{wt} \%$ pure tailing; S10, S20, S30 = 10, 20, and $30 \mathrm{wt} \%$ sludge zone; C10, C20, C30 = 10, 20 and $30 \mathrm{wt} \%$ settling zone; N10, N20, N30 = 10, 20, and $30 \mathrm{wt} \%$ non-floated; F10, F20, F30 = 10, 20, and $30 \mathrm{wt} \%$ floated.

\begin{tabular}{ccc}
\hline Formulation & Color & Munsell Color \\
\hline A0 & Red & $2.5 Y R$ 5/6 \\
R10, R20, S10, S20, S30, N10, & Red & $2.5 Y R 4 / 6$ \\
N20, N30, F10 & Reddish brown & $2.5 Y R 4 / 4$ \\
R30, C20, F20 F30 & Dark reddish brown & $2.5 Y R 3 / 4$ \\
C30 &
\end{tabular}

Analysis of the water absorption test results of the specimens showed that the addition of up to $30 \mathrm{wt} \%$ of tailings or their fractions to the soil did not significantly alter WA of the materials produced (Figure 6). Statistical analyses for non-normal data showed a significant difference only between C30 and test specimens with WA $\leq 16.03 \%$. The increase of molten flux content to clayey masses, which fills a larger number of pores due to the formation of melted phases during sintering, may explain the decrease in WA with the addition of tailings or their fractions. However, for WA, none of the formulations present restrictions for the manufacture of bricks, blocks (between $8 \%$ and $22 \%$ ), or tiles $(<20 \%)$, according to Brazilian standards and the literature $[18,20]$.

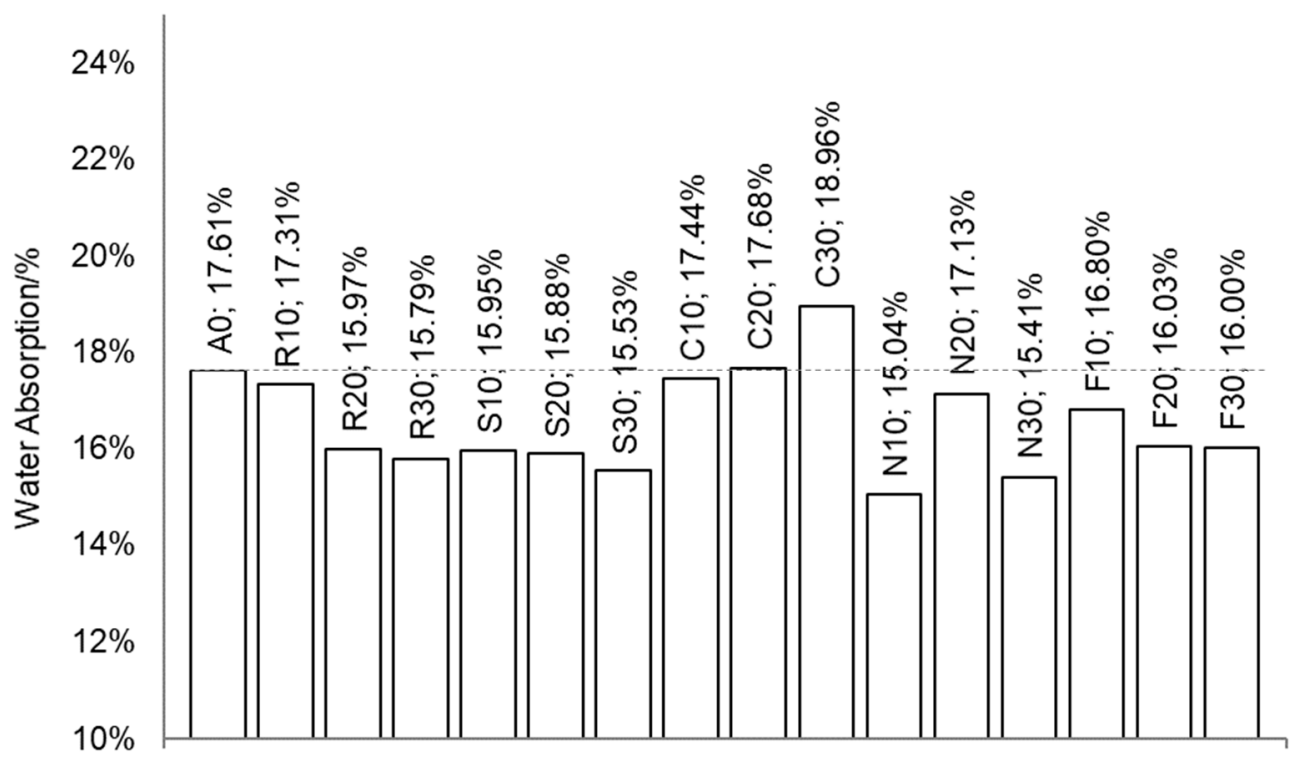

Figure 6. Water absorption of specimens with the addition of $0,10,20$, and $30 \mathrm{wt} \%$ of tailings, sludge zone, settling zone, non-floated and floated to the soil mass. A0 $=0 \mathrm{wt} \%$ residue; R10, R20 and R30 = 10, 20 and $30 \mathrm{wt} \%$ pure tailing; S10, S20, $\mathrm{S} 30=10,20$ and $30 \mathrm{wt} \%$ sludge zone; $\mathrm{C} 10, \mathrm{C} 20, \mathrm{C} 30=10,20$ and $30 \mathrm{wt} \%$ settling zone; N10, N20, N30 = 10, 20 and $30 \mathrm{wt} \%$ non-floated; F10, F20, F30 = 10, 20 and $30 \mathrm{wt} \%$ floated.

As observed for the WA, apparent porosity decreased with an increase in the content of tailings or their fractions in the soil mass, except with the addition of the settling zone fraction. The results in Figure 7 show apparent porosity values lower than $20 \mathrm{wt} \%$ for test specimens, except for the C 30 formulation. This is the limit value for ceramic materials, above which it is difficult to guarantee mechanical integrity of the pieces during transportation. 


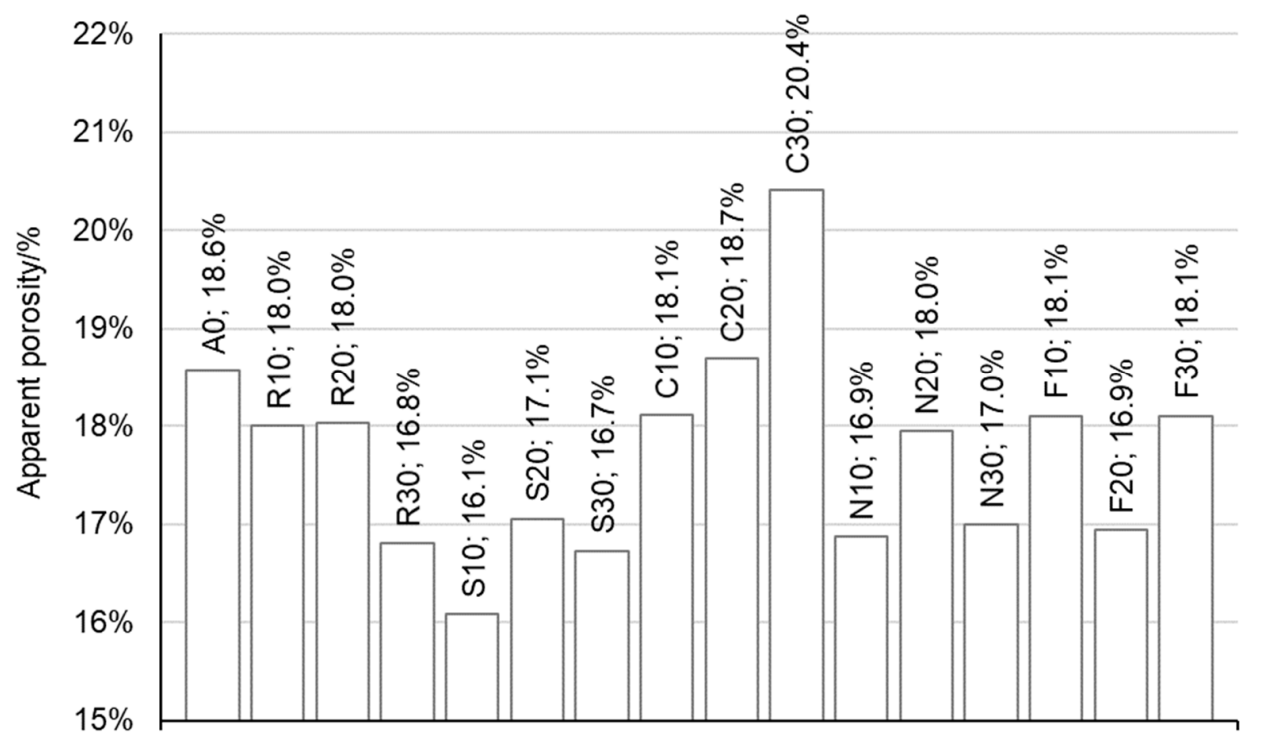

Figure 7. Apparent porosity of specimens with the addition of $0,10,20$, and $30 \mathrm{wt} \%$ of tailings, sludge zone, settling zone, non-floated, and floated to the soil mass. A0 $=0 \mathrm{wt} \%$ residue; R10, R20, and R30 = 10, 20 and $30 \mathrm{wt} \%$ pure tailing; S10, S20, $\mathrm{S} 30=10,20$, and $30 \mathrm{wt} \%$ sludge zone; $\mathrm{C} 10, \mathrm{C} 20, \mathrm{C} 30=10,20$, and $30 \mathrm{wt} \%$ settling zone; N10, N20, N30 = 10, 20, and $30 \mathrm{wt} \%$ non-floated; F10, F20, F30 = 10, 20, and $30 \mathrm{wt} \%$ floated.

Figure 8 shows the results of flexural strength $(\sigma)$ of sintered specimens. It can be observed that the addition of small amounts of tailings or their fractions to soil increases the mechanical strength of the pieces produced, which is more evident in relation to the sludge zone and the non-floated fraction. Regarding the minimum recommended limits for flexural strength, none of the specimens reached these levels, being 6.5 MPa for tile production, but most are above the $1.5 \mathrm{MPa}$ shown by Santos [13] for ceramic bricks. However, from the estimation of compressive strength, which can be taken as 10 times the flexural strength, all estimated values are above the minimum limit established by Brazilian standards for solid bricks and blocks with horizontal and vertical holes.

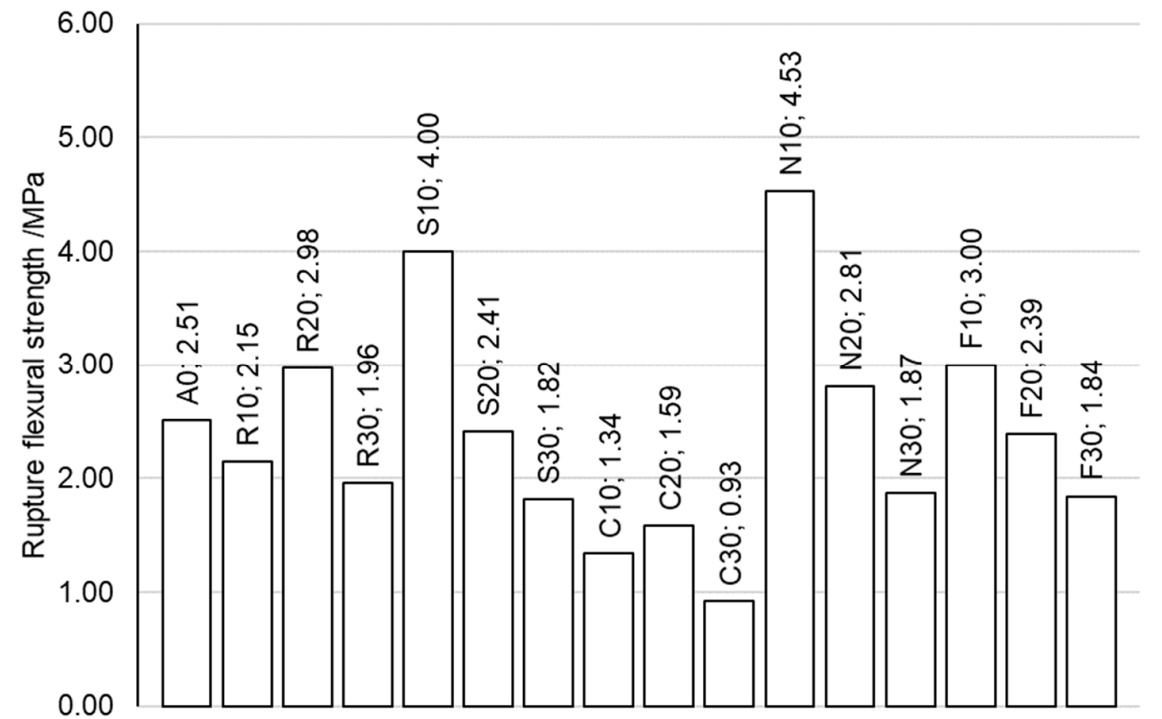

Figure 8. Flexural strength of specimens with $0,10,20$, and $30 \mathrm{wt} \%$ of tailings, sludge zone, settling zone, non-floated, and floated to the soil mass. A0 $=0 \mathrm{wt} \%$ residue; R10, R20, and $\mathrm{R} 30=10,20$, and $30 \mathrm{wt} \%$ pure tailing; S10, S20, S30 = 10, 20, and $30 \mathrm{wt} \%$ sludge zone; $\mathrm{C} 10, \mathrm{C} 20, \mathrm{C} 30=10,20$, and 30 $w \mathrm{t} \%$ settling zone; $\mathrm{N} 10, \mathrm{~N} 20, \mathrm{~N} 30=10,20$, and $30 \mathrm{wt} \%$ non-floated; F10, F20, F30 = 10, 20, and 30 $\mathrm{wt} \%$ floated. 
It can be observed that the addition of iron ore tailings or their fractions to soil greatly reduced the mechanical strength of the specimens, which is certainly a consequence of higher porosity in the products, although increased proportions of these materials added to the final soil mass decreased porosity and water absorption [30]. Another study using red residues showed flexural strengths lower than $5 \mathrm{MPa}$ [12]. However, the Tukey HSD statistical analysis did not show significant differences between test specimens produced with the addition of these tailings or their fractions and test specimens produced only with soil, without the proposed additives (A0), in the case of flexural strength. Differences were only observed between the most resistant and the least resistant pieces, albeit with low amplitudes of values of studied parameters.

The specimens with an increase of $30 \mathrm{wt} \%$ of tailings or their fractions to soil had their microstructure investigated using scanning electron microscopy (SEM) at a magnification of $100 \times$. Figure 9 shows a SEM micrograph obtained for test specimen A0, prepared only with soil from Cerâmica Baixio, without the addition of mining tailings or fractions thereof. In the image, the irregular surface of the fracture can be seen, whereby fine grains associated with the matrix formed by solidification of melted phases after sintering can be observed.

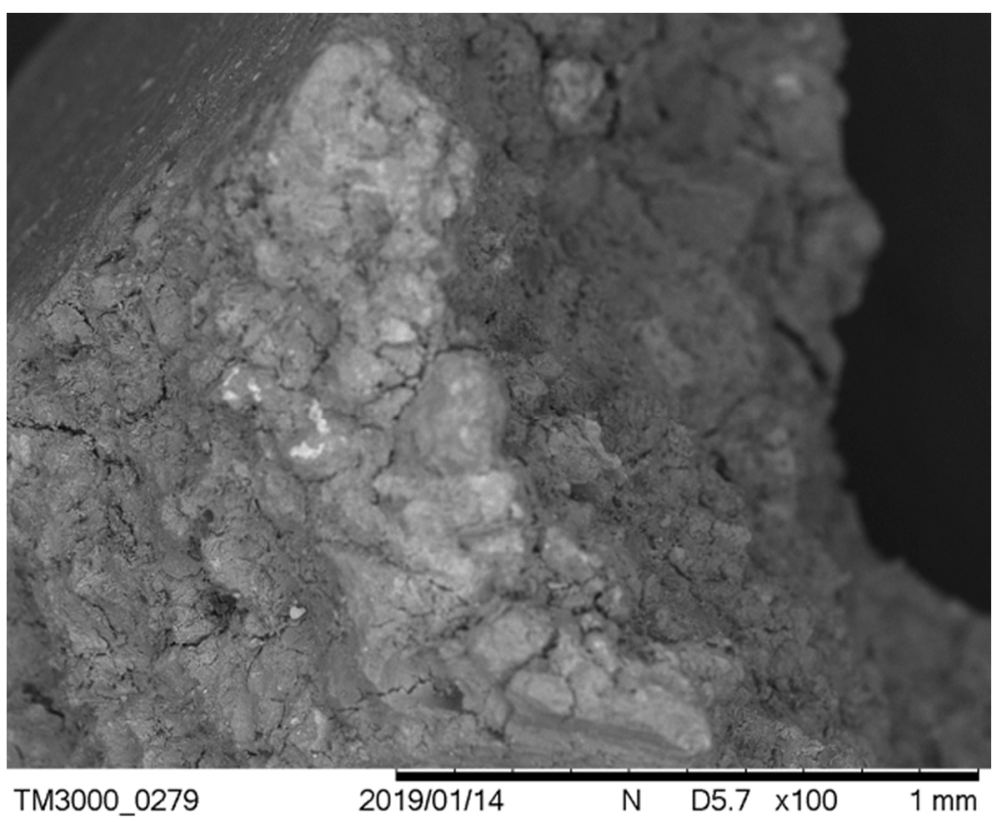

Figure 9. Scanning electron microscopy image of specimen A0 (0 wt \% of tailings).

Addition of $30 \mathrm{wt} \%$ of tailings to soil results in production of more fragile specimens (R30), with the presence of larger mineral grains (Figure 10), mainly quartz. However, these specimens present a greater densification and filling of the spaces between these grains, which can be confirmed by the decrease of apparent porosity in relation to A0 test specimens. The excess quartz of the tailings added to soil mass causes a marked reduction in the plasticity and mechanical strength of the mass $[8,10]$.

SEM images of specimens with the composition of $30 \mathrm{wt} \%$ of the sludge zone (S30; Figure 11A) indicate the presence of a high number of well-defined quartz grains. The significant occurrence of quartz in these specimens directly results from the sedimentation separation process, since granulometry has a direct influence on process yield and precipitates a large volume of quartz in bottom sludge. A relatively small number of quartz grains can be observed in specimens produced with $30 \mathrm{wt} \%$ settling zone (C30, Figure 11B), showing a greater uniformity of fracture surface, which results in a more fragile rupture with less flexural strength. 


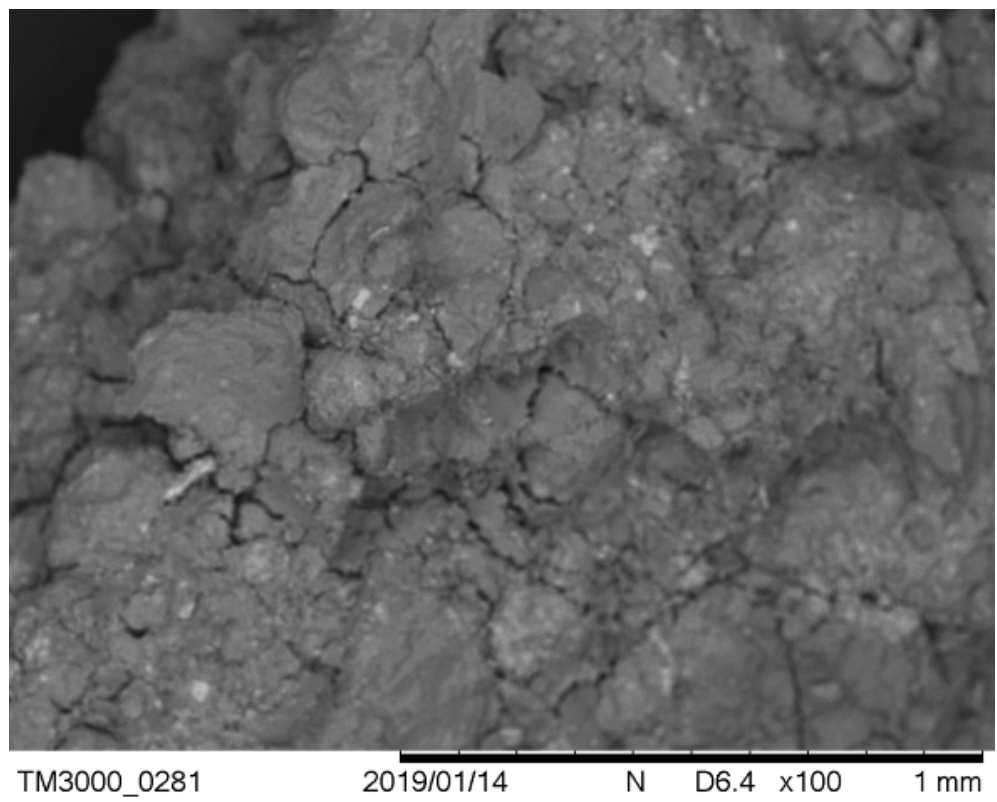

Figure 10. Scanning electron microscopy image of specimens R30 (30 wt $\%$ of tailings).
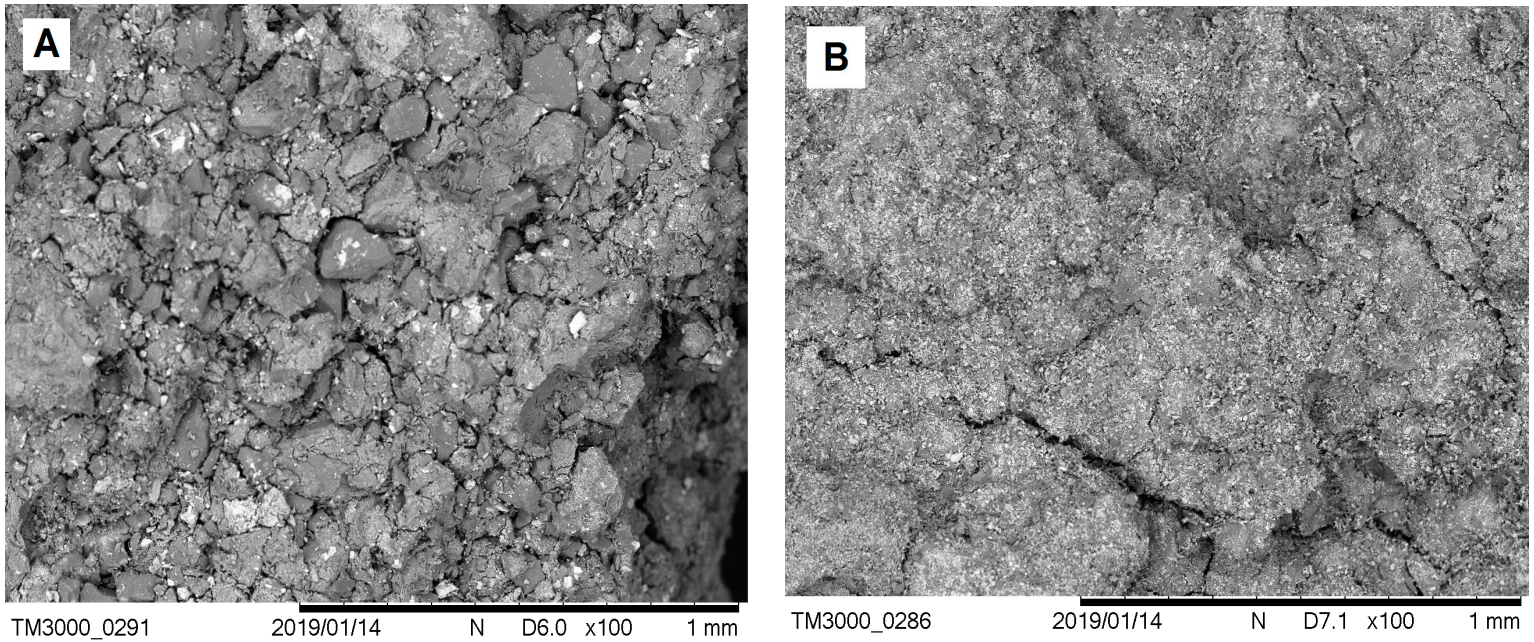

Figure 11. Scanning electron microscopy images of specimens S30 (30 wt\% sludge zone; (A)) and C30 (30 wt \% settling zone; (B)).

In relation to specimens with an increase of $30 \mathrm{wt} \%$ of non-floated (Figure 12A) and $30 \mathrm{wt} \%$ of floated (Figure 12B) to soil, a similarity in morphology can be observed with a glassy matrix of clay mass containing dispersed quartz grains, which is visible in the micrographs. However, the floated fraction gives a more incorporated and denser matrix, mainly due to higher kaolinite content compared to the non-floated fraction.

Analyzing SEM micrographs, a marked presence of quartz grains is visible in test specimens produced with the addition of mining tailings or fractions, except for those in which the sludge zone of sedimentation was used. Therefore, we should emphasize the care that must be taken with the proportion of quartz in the ceramic mass, since a very high proportion can reduce mechanical resistance and lead to the appearance of cracks in manufactured pieces.

In summary, increasing iron ore tailings or their fractions (sludge zone and non-floated and floated phases) to clay visibly increased quartz content in the final clayey mixture, favoring the formation of a silicate skeleton in specimens. As observed in SEM micrographs of specimens produced with the addition of the settling zone of sedimentation, the clay 
mass was relatively more uniform, with a low occurrence of quartz grains, and, as expected, presenting lower mechanical resistance.
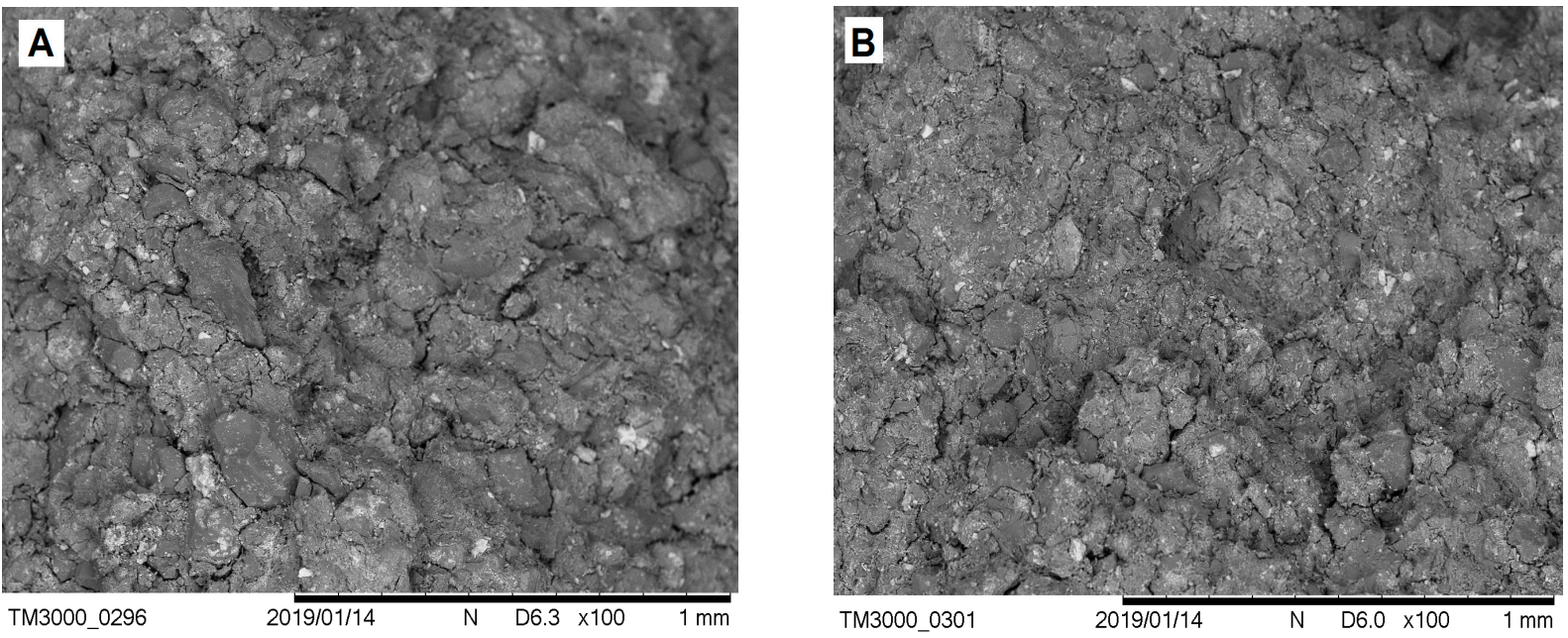

Figure 12. Scanning electron microscopy images of specimens $\mathrm{N} 30$ (30 wt $\%$ non-floated; (A)) and F30 (30 wt $\%$ floated; (B)).

\section{Conclusions}

Sedimentation fractions of investigated mining tailings showed distinct chemical and mineralogical characteristics, with the settling zone showing a relatively smaller average grain size and a higher proportion of ferruginous species. In relation to flotation, the obtained fractions have very similar characteristics, differing mainly in the higher concentration of goethite in the non-floated fraction and kaolinite in the floated fraction. However, flotation is a chemical separation process that agglutinates compounds with greater affinity, the better interacting minerals being separated into each fraction, favoring the formation of more chemically uniform fractions, which we demonstrated in the improvement of characteristics of specimens produced when we added these fractions to the soil.

We improved some characteristics of the ceramic specimens with the addition of tailings or their fractions to soil, as with linear shrinkage, which decreased as the proportion of sedimentation and flotation fractions increased. Mass loss and water absorption were also reduced with increasing proportions added to the soil for most specimens, except for those where we used the sedimentation settling zone.

Specimens with the addition of tailings or their fractions presented results that satisfied the minimum and maximum limits in the main mechanical tests recommended for the production of ceramic materials, especially the sludge, non-floated, and floated fractions. This achieved the aim of this study to obtain satisfactory results through co-processing the tailings or their sedimentation and flotation fractions with soil, except for in the case of mechanical resistance, which presented a reduction to values below the A0 standard.

Considering the results of improvement in certain characteristics of the specimens produced with the addition of fractions of mining tailings obtained in sedimentation and flotation, in relation to corresponding data obtained for the specimens manufactured with the addition of untreated tailings, we propose an alternative destination for these tailings fractions. In industry, these tailings undergo individualized processing, but their use in ceramics would avoid storage without a criterion of separation in dams, and provide a more noble purpose for such tailings and their fractions.

Author Contributions: Formal analysis and investigation, I.B.C.A. and B.V.P.; writing—original draft preparation, I.B.C.A.; writing-review, editing and visualization, L.C.D.C. and J.D.F.; supervision and project administration, A.B.R. All authors have read and agreed to the published version of the manuscript. 
Funding: This study was supported by FAPEMIG [APQ-03624-1 Candonga Network: Application of Developed Technologies and Studies of Technical and Economic Viability for Transformation and Assessment of Dredged Tailings of the Candonga Dam (Trans-forming the Disaster of Rio Doce into Local Opportunities)]. To GEPAEQ (Group of Studies and Research Applied to Chemical Engineering). To laboratories LIPEMVALE-UFVJM, LABCON/CDTN, SETEM/CDTN and LMC/UFV. To LMMA financed by FAPEMIG (CEX-112-10), SECTES/MG and RQ-MG (FAPEMIG: CEX-RED00010-14). JD Fabris and LCD Cavalcante are indebted to the National Council for Scientific and Technological Development (CNPq), for the financial support under the grants \# 304958/2017-4 and \# 313431/2017-5, respectively.

Institutional Review Board Statement: Not applicable.

Informed Consent Statement: Not applicable.

Data Availability Statement: Not applicable.

Conflicts of Interest: The authors declare no conflict of interest.

\section{References}

1. MME-Ministry of Mines and Energy. Anuário Estatístico do Setor de Transformação de Não Metálicos; MME: Brasília, Brazil, 2017.

2. ABDI-Brazilian Industrial Development Agency. Estudo Técnico Setorial da Cerâmica Vermelha: Subsídios para a Elaboração do Plano de Desenvolvimento Sustentável da Cadeia Produtiva de Cerâmica Vermelha; ABDI: Brasília, Brazil, 2016.

3. ANA-National Water Agency. Encarte Especial Sobre a Bacia do Rio Doce—Rompimento da Barragem em Mariana/MG; ANA: Brasília, Brazil, 2016.

4. Palu, M.C.; Julien, P.Y. Modeling the Sediment Load of the Doce River after the Fundão Tailings Dam Collapse. J. Hydraul. Eng. 2019, 145. [CrossRef]

5. Rodrigues, R.T.; Rubio, J. DAF-Dissolved air flotation: Potential applications in the mining and mineral processing industry. Int. J. Miner. Process. 2007, 82, 1-13. [CrossRef]

6. Peres, A.E.C.; Mapa, P.S. Innovative flotation routes in an iron ore concentrator. In XXIV International Mineral Processing Congress; Science Press: Beijing, China, 2008; Volume 3, pp. 4205-4210.

7. Batisteli, G.M.B.; Peres, A.E.C. Residual amine in iron ore flotation. Miner. Eng. 2008, 21, 873-876. [CrossRef]

8. Goes, J.R.; Azevedo, T.F.; Dutra, T.X.C.; Santos, V.B.; Severo Junior, J.B.; Barreto, L.S. Evaluation of the potenciality of clays from the Calumbi and Riachuelo geological formation in Sergipe, Brazil, for application in ceramic tiles. Cerâmica 2014, 60, 211. [CrossRef]

9. Formiga, F.L.; Andrade, J.C.S.; Araujo, P.A.S.; Macedo, D.A.; Martinelli, A.E.; Nascimento, R.M.; Paskocimas, C.A. Indústrias Cerâmicas da Região do Seridó (RN): Panorama Sócio-econômico e Caracterização Tecnológica de Matérias-primas. Cerâm. Ind. 2013, 18, 30-36. [CrossRef]

10. Dutra, R.P.S.; Araujo, P.A.S.; Macedo, R.M.P.R.; Nascimento, R.M.; Gomes, U.U.; Martinelli, A.E.; Paskocimas, C.A. Desenvolvimento de Formulações de Massas para a Indústria de Cerâmica Vermelha do Rio Grande do Norte. Cerâm. Ind. 2006, 11, 41-46. Available online: http://www.ceramicaindustrial.org.br/journal/ci/article/5876572a7f8c9d6e028b46fc (accessed on 5 January 2021).

11. Klein, C.; Dutrow, B. Manual de Ciência dos Minerais, 23rd ed.; Bookman: Porto Alegre, Brazil, 2012.

12. Ribeiro, L.D.S.; Babisk, M.P.; Prado, U.S.D.; Monteiro, S.N.; Vieira, C.M.F. Incorporation of in natura and calcined Red Muds into clay ceramic. Mater. Res. 2015, 18, 279-282. [CrossRef]

13. Santos, P.S. Ciência e Tecnologia de Argilas, 2nd ed.; Edgard Blücher: São Paulo, Brazil, 1989.

14. Munsell. Munsell Soil Color Charts; Macbeth Division of Kollmorgen Corporation: Baltimore, MD, USA, 2009.

15. Dutra, R.P.S. Efeito da Velocidade de Aquecimento nas Propriedades de Produtos da Cerâmica Estrutural. Ph.D. Thesis, Universidade Federal do Rio Grande do Norte, Natal, Brazil, 1 March 2007.

16. Savazzini-Reis, A.; Sagrillo, D.; Possamai, V.; Oliveira, J.D.N.D.; Teixeira, P.G.; Valenzuela-Diaz, F.R. Characterization and Evaluation of Ceramic Properties with Spherical and Prismatic Samples of Clay Used in Red Ceramics. Mater. Res. 2017, 20, 543-548. [CrossRef]

17. Coutinho, N.C.; Vieira, C.M.F. Caracterização e incorporação de cinza de resíduo sólido urbano em cerâmica vermelha. Cerâmica 2016, 62, 249-255. [CrossRef]

18. Brito, I.P.; Almeida, E.P.; Neves, G.A.; Menezes, R.R.; Silva, V.J.; Santana, L.N.L. Assessment of new clay deposits of Paraíba State for application as ceramic raw materials. Cerâmica 2015, 61, 391-398. [CrossRef]

19. Xavier, G.D.C.; Azevedo, A.R.G.D.; Alexandre, J.; Monteiro, S.N.; Pedroti, L.G. Determination of useful life of red ceramic parts incorporated with ornamental stone waste. J. Mater. Civ. Eng. 2018, 31. [CrossRef]

20. ABNT-Brazilian Association of Technical Standards. Componentes Cerâmicos; ABNT: Rio de Janeiro, Brazil, 2005; NBR 15270-1.

21. Almeida, P.H.S.; Franco, J.M.; Tavares, C.R.G. Influence of clay type in the solidification stabilization process of textile sludge. Cerâmica 2015, 61, 137-144. [CrossRef] 
22. Câmara, A.P.C.; Medeiros, L.C.; Macedo, D.A.; Galdino, J.N.; Melo, D.M.A.; Melo, M.A.F. Caracterização Físico-mecânica e Ambiental de Cerâmica Estrutural com Imobilização do Íon Manganês. Cerâm. Ind. 2013, 18, 39-42. [CrossRef]

23. Santos, C.P.; Oliveira, H.A.; Oliveira, R.M.P.B.; Macedo, Z.S. Caracterização de argilas calcárias utilizadas na produção de revestimentos cerâmicos no Estado de Sergipe-Brasil. Cerâmica 2016, 62, 147-156. [CrossRef]

24. ABNT-Brazilian Association of Technical Standards. Componentes Cerâmicos-Telhas_Terminologia, Requisitos e Métodos de Ensaio; ABNT: Rio de Janeiro, Brazil, 2005; NBR 15310.

25. Idrissi, H.B.; Daoudi, L.; Ouahabi, M.; Collin, F.; Fagel, N. The influence of clay composition and lithology on the industrial potential of earthenware. Constr. Build. Mater. 2018, 172, 650-659. [CrossRef]

26. Boussen, S.; Sghaier, D.; Chaabani, F.; Jamoussi, B.; Bennour, A. Characteristics and industrial application of the Lower Cretaceous clay deposits (Bouhedma Formation), Southeast Tunisia: Potential use for the manufacturing of ceramic tiles and bricks. Appl. Clay Sci. 2016, 123, 210-221. [CrossRef]

27. Abdelmalek, B.; Rekia, B.; Youcef, B.; Lakhdar, B.; Nathalied, F. Mineralogical characterization of Neogene clay areas from the Jijel basin for ceramic purposes (NE Algeria-Africa). Appl. Clay Sci. 2017, 136, 176-183. [CrossRef]

28. Dondi, M.; Raimondo, M.; Zanelli, C. Clays and bodies for ceramic tiles: Reappraisal and technological classification. Appl. Clay Sci. 2014, 96, 91-109. [CrossRef]

29. He, H.; Yue, Q.; Qi, Y.; Gao, B.; Zhao, Y.; Yu, H.; Li, J.; Li, Q.; Wang, Y. The effect of incorporation of red mud on the properties of clay ceramic bodies. Appl. Clay Sci. 2012, 70, 67-73. [CrossRef]

30. Colombo, A.L.; Laraz, F.B.; Júnior, S.; Lima, R.H.C.; Berti, L.F. Evaluation of kaolin and bauxite from the Amazonian region addition on mechanical-, physical-, chemical properties and microstructural characterization of red ceramic industry clay of Manaus metropolitan region. Matéria 2018, 23. [CrossRef] 